\title{
Sjálfsmynd, framandleiki og tungumál í verkum Matéos Maximoff: rómíska î íslenskum býðingum
}

1.

$\mathbf{R}$ ómafólki bregður oft fyrir í bókmenntum og kvikmyndum en R sjaldgæft er að pessi verk séu samin eða gerð af rómískum höfundum eða öðrum sem hafa pekkingu á menningu peirra og samfélagi. ${ }^{1}$ Af pví leiðir að sú staðalmynd sem dregin er upp af „Sígaunanum“ á lítið skylt við veruleikann og hefur hún enn fremur stuðlað að pví að búa til framandi og dularfulla ímynd af pessu fólki sem, í mörgum tilvikum, hefur verið á faraldsfæti um aldaraðir og sætt fordómum, andúð og ofsóknum vegna uppruna síns. ${ }^{2}$ Pað er ekki ýkja langt síðan Rómafólk fór sjálft að setja sögur sínar og kveðskap niður á blað. Líklegt er að ritgerð eftir Alexander Germano, sem kom út í Rússlandi árið 1915, hafi verið fyrsta prentaða verkið á rómísku, sem er ekki eitt tungumál heldur samheiti fyrir margar

1 Samkvæmt Ian Hancock er Romani pað orð sem allir „Sígaunar“ eru sáttir við að nota um sig; Ian Hancock, We are the Romani People. Ame sam e Rromane dzene, Hatfield: University of Hertfordshire Press, 2013 (2002), bls. xviii-xxii. Orðið „Sígauni“ er nú almennt talið niðrandi á íslensku og pví er „Rómafólk“ gjarnan notað í pess stað (sbr. https://malid.is/leit/rómafólk); rómískur er bá lýsingarorð og rómíska heiti tungumálsins, sbr. https://idordabanki.arnastofnun.is/faersla/730649, [skoðað 20. desember 2019].

2 Um petta fjallar Ian Hancock t.d. í inngangi sínum að bókinni The Roads of the Roma - a PEN anthology of Gypsy writers, Ian Hancock, Siobhan Dowd, Rajko Djuric (ritstj.), Hatfield: University of Hertfordshire Press. On behalf of Pen American Center, bls. 9-21. Sjá líka: Mile Fucíková, „Les images des Tsiganes dans la littérature française du 19e siècle. Les origines de la naissance d'un mythe“, Études tsiganes 25/2006, bls. 10-35; nær okkur: Norma Montesino, „The 'Gypsy Question' and the Gypsy expert in Sweden“, Romani Studies 5, 11(1)/2001, bls. 1-23. 
skyldar mállýskur. ${ }^{3}$ Fyrstu skáldverkin komu svo út á millistríðsárunum (1918-1939) og undanfarna áratugi hefur rómískum rithöfundum fjölgað umtalsvert. ${ }^{4}$

Bókmenntir Rómafólks hafa pó sjaldan komið fyrir augu íslenskra lesenda og svo virðist sem „Prjú Sígaunaljóð“, í pýðingu Einars Braga skálds og rithöfundar, séu einu textarnir sem komið hafa út á íslensku. Ljóðin fjalla um hestapjófnað, flótta og ástarsorg og birtust í tímaritinu Birtingi árið 1966. Tvö peirra eru eignuð serbnesku skáldkonunni Ginu Raňičić en ekki kemur fram hver höfundur priðja ljóðsins sé. ${ }^{6}$ Fólki af rómískum uppruna hefur farið fjölgandi á Íslandi undanfarna áratugi og brýnt er að gera menningu pess, sögu og menningararfi betri skil. ${ }^{7}$

Ritverk Rómafólks eru margvísleg en ekki er óalgengt er að pau tengist sjálfsmynd pess, menningu og sagnaarfi. ${ }^{8}$ Pau veita einstaka innsýn í líf og lifnaðarhætti pess samfélags sem pau eru sprottin úr og eru í senn framandi og kunnugleg. Í pessari grein verður sjónum beint að rómíska rithöfundinum Matéo Maximoff, en ekkert benti til pess að hinn ungi Maximoff, sem sótti skóla „náttúrunnar, skógarins, stíganna og lækjanna“9 ætti eftir að feta leið hins ritaða orðs. Einkum verður fjallað um vægi eða hlutverk rómíska tungumálsins í textum

3 Germano pýddi einnig verk Púshkíns á rómísku, skrifaði um málfræði rómísku og sögu Rómafólks; Hancock, The Roads of the Roma, bls. 11; Milena Hübschmannová, „Alexander Vyacheslavovoch Germano“, ROMBASE. http://rombase.uni-graz.at/, [skoðað 30. nóvember 2019]. Um rómísku, sjá nánar nmgr. 29.

4 Um petta fjallar Sofiya Zahova í greininni „Romani Language Literature“, Yaron Matras og Anton Tenser (ritstj.), The Palgrave Handbook of Romani Language and Linguistics, Houndmills: Palgrave Macmillan, 2020, bls. 539-569.

5 „Prjú Sígaunaljóð“, Birtingur 12 (1-3)/1966, bls. 13-14.

6 Talið er víst að ljóð skáldkonunnar Ginu Raňičić (?-1890) hafi verið aðlöguð og peim breytt af austurríska sígaunafræðingnum Heinrich von Wlislocki; Milena Hübschmannová, „Alexander Vyacheslavovich Germano“.

7 Árið 2020 kemur út hjá Stofnun Vigdísar Finnbogadóttur í erlendum tungumálum safn smásagna eftir höfunda af rómískum uppruna. Ritstjórar bókarinnar eru Sofiya Zahova, sérfræðingur í menningu og málefnum Rómafólks, og Ásdís R. Magnúsdóttir. Ian Hancock, prófessor við University of Texas at Austin, skrifar inngang að sögunum, og Sofiya eftirmála. Í bókinni verða rúmlega tuttugu smásögur eftir sex höfunda: Georgijy Tsvetkov, Ilona Ferková, Jess Smith, Jorge Emilio Nedich, Jovan Nikolic og Matéo Maximoff. Sögurnar eftir Maximoff eru allar úr safninu La poupée de Mameliga. Le livre de la peur, Romainville: Chez l'auteur, 1986.

8 Sjá nánar Cécile Kovácsházy, „Pour une définition des littératures tsiganes/romani“, Études tsiganes 37/2009, bls. 4-7; Sofiya Zahova, „Romani language literature“, bls. 17-26; Paola Toninato, Romani Writing: Literacy, Literature and Identity Politics, New York: Routledge, 2014, sjá einkum 2. hluta verksins, „The Rise of Romani Literature“.

9 Matéo Maximoff, Dites-le avec des pleurs. Récit, Romainville: Chez l'auteur, 1990, bls. 52. 
hans og tekin dæmi úr smásagnasafninu La poupée de Mameliga. Le livre de la peur (Brúða Mameligu. Bók óttans) sem kom út árið 1986.

Matéo Maximoff (1917-1999) ólst upp við að heyra sögur frá Rússlandi par sem prjár kynslóðir ættingja hans í föðurætt hans höfðu búið. ${ }^{10}$ Langafi Matéos hafði verið præll í Rúmeníu áđur en prælahald var lagt niður par í landi árið 1855. Hann fór pá til Rússlands eins og margir af Kalderash-ættflokkinum sem hann tilheyrði, og par fékk hann nafnið Maximoff vegna pess hversu hávaxinn hann var. Kalderash-Rómafólk var pekkt fyrir að smíða potta, katla og pönnur og gera við eftir pörfum. ${ }^{11}$ Afi Matéos var fjórtán barna faðir og fjölskyldan ferðaðist milli markaðstorga í porpum og bæjum í Síberíu, Kína og víoar og kom til Vestur-Evrópu um 1910. Foreldrar Matéos hittust árið 1916 og hann fæddist pegar fjölskyldan var stödd í Barselóna, árið 1917, líklega 17. janúar. Faðir hans var hljóðfæraleikari og koparsmiður eins og faðir hans og afi. Foreldrar Matéos fóru frá Spáni pegar hann var priggja ára en móđirin lést af barnsförum pegar sjötta barn peirra hjóna kom í heiminn í Belgíu árið 1925. Fjölskyldan kom sér pá fyrir í tjöldum í Romainville í nágrenni Parísar. Matéo varð munaðarlaus fjórtán ára gamall og sá, ásamt frændum sínum, um systkini sín með pví að prífa og gera við potta og eltitrog bakara. Premur árum síđar heimsótti hann móðurfjölskyldu sína í Suður-Frakklandi og tók pátt í að sjá um ferðabíó fjölskyldunnar. Hún tilheyrði Manouche-ættflokkinum og hann var pekktur fyrir slíka starfsemi. Allt lék í lyndi par til Matéo tók pátt í ryskingum milli tveggja fjölskyldna par sem prír lágu í valnum áour en yfir lauk. Hann var tekinn fastur, sat inni í fjóra mánuði og pað var lögmaður hans, Jacques Isorni, sem fékk hann til að segja frá

10 Um ævi Maximoffs, sjá til dæmis Milena Hübschmannová, „Matéo Maximoff“, ROMBASE, [skoðað 15. nóvember 2019]; Gérard Gartner, Matéo Maximoff. Carnets de route, Paris: Alteredit, 2006; Anne-Isabelle Lignier, „Matéo Maximoff, chantre des cultures tsiganes“, Études Tsiganes 60(1)/2017, bls. 7-15.

11 Nafn Kalderash-Rómafólks (úr rúm. caldare - stór pottur) vísar til peirrar iðju sem pað stundaði. Um ólíka undirhópa Rómafólks, sjá t.d. Milena Hübschmannová, „Roma Sub Ethnic Groups“, ROMBASE [skoðað 15. desember 2019]; Ian Hancock, We are the Romani People. Ame sam e Rromane dzene, bls. xviii-xxii; sami, The Roads of the Roma - a PEN Anthology of Gypsy Writers, bls. 9-21. 
pessari atburðarás og lifnaðarháttum Manouche-ættflokksins. Isorni lýsti fyrsta fundi sínum með Maximoff í fangelsinu með pessum orðum:

Hann sagði mér að hann væri einn fárra Sígauna sem kynnu að lesa og skrifa. Hann hafði lært sjálfur í skini varðeldanna og á ferð í vögnunum sem peir kalla vurdon á sínu tungumáli. [...] Matéo Maximoff leiddist í klefanum sínum og ég stakk upp á pví að hann keypti skrifblokk í fangelsisbúðinni og skrifaði fyrir mig um Sígaunalífið. Ég ætlaði að nota pessa punkta í varnarræðunni í Puy-de-Dôme. ${ }^{12}$

Í stað minnispunkta skrifaði Maximoff hins vegar heila skáldsögu, Les Ursitory, sem kom út árið 1946. Detta er saga sem afi hans og amma höfðu sagt honum, saga par sem örlagavættir (róm. ursitori) og nornir spila með ástir og líf karla og kvenna.

Maximoff lenti í fangabúðum í október 1939, stuttu eftir að Frakkland hafði lýst yfir strîði gegn Pýskalandi. Hópar Rómafólks tóku sig upp og flýðu suður á bóginn. Maximoff-fjölskyldan var stoppuð á landamærum Frakklands og Spánar og vísað í fangabúðir fyrir flökkufólk par sem hún dvaldi ásamt fleirum við illan aðbúnað í tæp prjú ár. Árið 1944 kom hann sér aftur fyrir í nágrenni Parísar og upp frá pví barðist hann fyrir viðurkenningu á pjóðarmorði Rómafólks í sî̉ari heimsstyrjöldinni. Maximoff ferðaðist mikið, tók ljósmyndir, rak kaffihús og vann með ýmsum pekktum kvikmyndagerðarmönnum og ljósmyndurum; hann hafði meðal annars pann starfa að vera eins konar milligöngumaður milli peirra og Rómafólks og var jafnvel gagnrýndur af sínu fólki fyrir að segja of mikið um siði peirra og venjur og ásakaður um að viðhalda staðalmyndum. Hann mætti ýmsu mótlæti, til dæmis í samstarfi sínu við franska bókaforlagið Flammarion, og honum gekk illa að fá franskan ríkisborgararétt, sem hann sótti ítrekað um. Eins og púsundir Rómafólks snerist Maximoff til kristinnar trúar á sjöunda áratugnum; í trúnni sá hann frelsi fyrir fólk sitt og hann gerðist prestur î Hvítasunnusöfnuðinum

12 Milena Hübschmannová, „Matéo Maximoff“. Allar býðingar á íslensku í greininni eru mínar nema annað sé tekið fram. 
og vann árum saman að pýðingu Biblíunnar á rómísku. ${ }^{13}$ Maximoff lést árið 1999 og í París er nú að finna menningarmiðstöð Rómafólks sem ber hans nafn: Médiathèque Matéo Maximoff. ${ }^{14}$

Matéo Maximoff gekk ekki í skóla en pabbi hans kenndi honum að telja upp að tíu og að pekkja stafina. Svo lærði hann sjálfur að lesa og skrifa. Fyrsta tungumál hans var rómíska, en franskan var honum einnig mjög töm og hann skrifaði langflest verka sinna á frönsku par sem meiri líkur voru á að pau vektu áhuga útgefenda og peirra lesenda sem Maximoff hafði í huga við skrifin. Hann samdi um eitt hundrað ljóð, flest prósaljóð skrifuð í stílabók á tímum sîđari heimsstyrjaldar og hafa fæst peirra verið gefin út; skáldsögur, smásagnasafn, endurminningabækur og ljósmyndabók, Les Gens du voyage eða Flökkufólk, enda ferðaðist hann víða með myndavélina, festi á filmu рað sem fyrir augu bar og safnaði myndum. ${ }^{15}$ Einnig hélt hann dagbók par sem hann skrásetti bæði verð á brauði, ferðir sínar og fundi með frægu fólki; hann skrifaði fjölmargar greinar í tímaritið Études tsiganes, sem hann tók sjálfur pátt í að stofna árið $1955 .{ }^{16}$

Maximoff var í senn sagnamaður, rithöfundur og ötull baráttumaður fyrir viðurkenningu á Rómafólki og flökkufólki, tungumáli peirra og menningu. Pangað sótti hann iðulega innblástur og í mörgum verka hans er að finna alls kyns upplýsingar og fróðleik um siði og menningu Rómafólks sem fléttast inn í sögupráð verka hans án hiks eða truflunar. Samfélagsleg útilokun, ásakanir og andúð í garð Rómafólks í gegnum aldirnar var honum hugleikin og í sjálfsævisögulegu frásögninni Dites-le avec des pleurs (Segið pað með tárum) segir hann frá örlögum hundruð púsunda Sígauna í síðari heimsstyrj-

13 Um prestinn Matéo, sjá Patrick Williams, „Le Pasteur Matéo“, Études Tsiganes 60(1)/2017, bls. 142-158. Um útbreiðslu kristni meðal Rómafólks í Frakklandi, sjá: „La mission évangélique tzigane en France“, Le musée protestant, https://www.museeprotestant.org/notice/la-mission-evangelique-tzigane-de-france/.

14 Frekari upplýsingar má finna á vefsíðu Fnasat (Fédération nationale des associations solidaires d'action avec les Tsiganes et les Gens du voyage), http://www.fnasat.asso.fr, skoðað 20. desember 2019.

15 Matéo Maximoff, Les Gens du voyage, Romainville: Chez l'auteur, 1995; Antoine Le Roux, „Matéo Maximoff, écrivain et photographe“, Études Tsiganes 60(1)/2017, bls. 96-114.

16 Cécile Kovácsházy, „Matéo Maximoff, romancier. Une vie pour la littérature“, Études Tsiganes 60(1)/2017, bls. 72-95, hér bls. 76 . 
öld í fanga- og útrýmingarbúðum nasista. ${ }^{17}$ Fangabúðir Rómafólks í Frakklandi í styrjöldinni eru einnig sögusvið skáldsögunnar La septième fille (Sjöunda dóttirin) frá árinu 1969, par sem ellihrum galdrakona reynir á nokkrum dögum að miðla aldagamalli visku sinni til kornungs arftaka síns - sjöundu dóttur sjöundu dóttur - til pess að hún glatist ekki. Hér fellir Maximoff fumlaust hjátrú og galdra inn í lýsingar á sögulegum atburðum eins og ekkert sé eðlilegra. ${ }^{18}$ Hann lýsir einnig lífsmáta sem einkennist af sífelldum ferðalögum og, oftar en ekki, fátækt í samfélagi sem hefur horn í sîđu flökkufólks en neyðir pað engu að sî́ur í sífellu til pess að taka sig upp og leita að nýjum áfangastað. Sorg og gleði koma saman í ljóðinu „Je vous vend mes larmes“ (Ég sel ykkur tár mín) ${ }^{19}$ :

Ég sel ykkur tár mín.

Pótt ég sé enn lítill, er hjarta mitt stórt.

Pótt ég sé enn barn, finn ég til eins og fullorðinn maður.

Jafnaldrar mínir una glaðir við leik.

En ég verð að gráta.

Og par sem ég á ekkert

sel ég ykkur tár mín.

Ég horfi á börnin í kringum mig, pau hafa engin tár til sölu, aðeins tár sársaukans sem falla til jarðar og blandast eðjunni.

Ég strýk tárin af kinnunum

og sel pau fólki sem kann ekki að gráta.

17 Sjá t.d. Emmanuel Filhol, „L'exclusion et la tragédie des Tsiganes dans l'histoire: « Dites-le avec des pleurs » de Matéo Maximoff, Versant : revue suisse des littératures romanes 57/2010, bls. 125-147; Ulrich Baumann, „From the Gypsy's Point of View: Politique et mémoire au travers de la vie et l'œuvre de Matéo Maximoff", Études Tsiganes 60(1)/2017, bls. 115-133.

18 Umfjöllun um pessa skáldsögu og trú Rómafólks má t.d. finna í Kathy Comfort, Refiguring Les Années Noires: Literary Representations of the Nazi Occupation, Lanham, Boulder, New York, London: Lexington Books, 2019, sjá einkum 4. kafla: „Matéo Maximoffs La Septième fille. A Roma Testimony of Internment", bls. 81-106.

19 Matéo Maximoff, „Je vous vends mes larmes“, 1. febrúar 1983. Ég pakka Nouku Maximoff fyrir að veita leyfi fyrir birtingu og pýðingu á pessu ljóði. 
En hvað vil ég í staðinn

nema huggun?

Ef einhver elskar mig,

sel ég honum ekki tár mín,

ég gef bau,

pað eru gleðitár.

Pað kemur heldur ekki á óvart að gildi nýrrar trúar fléttist inn í verk hans, til dæmis í skáldsögunni Condamné à survivre (Dæmdur til að lifa af) par sem söguhetjan parf að gera upp við sig hvort hún fyrirgefur svörnum óvini sínum, eins og kristnin býður henni að gera, eða drepur, eins og reglur Rómafólks kveða á um í pessu tilfelli. Sögusvið skáldsögunnar teygir sig yfir mörg lönd en staðarnöfn eru pó sjaldséð, pví eins og höfundur og sögumaður segir:

Höfundur pessarar bókar hefur vísvitandi látið pað ógert að nefna nöfn landa og bæja par sem atburðirnir sem hann segir frá gerðust. EkkiRómamaður parf ekki að pekkja mikið til landafræði og mannkynssögu til pess að geta sér til um nöfnin. [...] Lesandi af rómískum uppruna mun ekki eiga í neinum vandræðum með að vita hvar hann er. Hann pekkir staðina. En Rómafólk á erfitt með að muna hvað peir staðir heita sem pað fer um. Í augum pess er bær bara bær, og ekkert annað! Ef Rómamaður man eftir ákveðnum bæ er pað vegna pess að eitthvað sem snerti hann eða fjölskyldu hans gerðist par. Petta er til dæmis bærinn par sem hann keypti skyrtu eða buxur. Nú eða bærinn par sem hann fékk að eyða nóttinni í fangaklefa vegna pess að húsbílnum hans var ekki lagt á réttum stað o.s.frv. ${ }^{20}$

Maximoff gerir gjarnan hlé á frásögninni í skáldverkum sínum og skýtur inn sögulegum eða sagnfræðilegum fróðleik um líf Rómafólks. I skáldsögunni Savina kemur fram að heilt líf getur reynst of stutt til að bæta fyrir mistökin sem felast í pví að virða ekki fornar reglur rómíska samfélagsins og kalla pannig yfir sig bölvun og skömm. ${ }^{21}$ Smásagan „La Pivli de Chandiri“ (Ekkja Chandiris) fjallar um dapur-

20 Matéo Maximoff, Condamné à survivre, Romainville: Chez l'auteur, 1984, bls. 180.

21 Savina, Paris: Flammarion, 1957, bls. 119, sjá Cécile Kovácsházy, „Matéo Maximoff, romancier. Une vie pour la littérature“, bls. 78. 
leg örlög ekkju manns sem deyr í fangavist. Par segir frá lífsskilyrðum fanga sem sendir eru til Síberíu til að taka út refsingu sína; leiðin pangað, löng, ströng og lífshættuleg, pjónar hlutverki fangelsismúra og á leiðarenda byggja fangarnir svo sjálfir varnarvegg um porp sitt til að verjast árásum villidýra en geta pó ekki varist sínum eigin draugum. ${ }^{22}$ Í smásagnasafninu má auk pess finna skýringar eða athugasemdir í lok nánast hverrar sögu par sem höfundurinn útlistar pá siði, hjátrú eða atburði sem sagt er frá í verkinu. Sem dæmi má nefna pann sið að gefa öllum gælunafn, að tala í hálfum hljóðum um látið fólk, að refsa stúlkum og konum grimmilega fyrir að óhlýðnast föður sínum eða eiginmanni eins og í smásögunni „Le sang impur“ (Óhreint blóð) par sem faðir drepur dóttur sína sem hefur lagt lag sitt við ekki-Rómamann og ber barn hans undir belti. Í athugasemd við söguna útskýrir Maximoff gamla fordóma Rómafólks í garð blandaðra hjónabanda og barna sem af peim fæðast en tekur svo fram að petta hafi mikið breyst, hann hafi sjálfur gengið að eiga svissneska konu og eigi tvær dætur sem gifst hafi Frökkum. ${ }^{23}$ Mikilvægt hlutverk kris, eða hefðbundins dómstóls Rómafólks, kemur líka vel í ljós í sögum hans; í kris koma karlar ættflokksins saman, ræða pau mál sem upp hafa komið og útkljá samkvæmt sínum lögum og reglum. ${ }^{24}$

Eins og bókmenntafræðingurinn Cécile Kovácsházi bendir á virðast skáldverk Maximoffs renna saman í eina stærri „sögu“ (fr. saga) eða eins konar „hetjuljóð“ sem nær frá byrjun 19. aldar til loka peirrar 20. par sem höfundurinn rekur sögu Rómafólks eins og um eina pjóð (fr. race) sé að ræða. Hann segir frá sameiginlegri baráttu peirra og dregur upp sameiginlega og sameinandi sjálfsmynd, andspænis „hinum“, ekki-Rómafólki eða Gayziés. ${ }^{25}$ Hún bendir einnig á að tvennt vaki fyrir höfundinum, fyrir utan pað að segja sögu: annars vegar að sýna að Rómafólk eru manneskjur sem koma skuli fram við sem mann-

22 Sagan er í smásagnasafninu La poupée de Mameliga.

23 La poupée de Mameliga, bls. 140.

24 Sjá t.d. skáldsögurnar Savina og Condamné à survivre. Um kris: Ronald Lee, „The Rom-Vlach Gypsies and the Kris-Romani“, Gypsy Law. Romani Legal Traditions and Culture, ritstj. Walter O. Weyrauch, Berkeley, Los Angeles, London: University of California Press, 2001, bls. 188-230.

25 Cécile Kovácsházy, „Matéo Maximoff, romancier. Une vie pour la littérature“, bls. 76-77. Pessa sýn á Rómafólk má tengja viðleitni rómískra rithöfunda og fræðimanna til að skapa samstöðu meðal ólíkra hópa og samfélaga Rómafólks og tilfinningu fyrir pví að tilheyra sömu pjóð pótt Rómafólk eigi ekki sameiginlegt heimaland; sjá t.d. Paola Toninato, Romani Writing: Literacy, Literature and Identity Politics, einkum 3. hluta verksins: „The Politics of Romani Writing“. 
eskjur, pað felist í pví að brjóta niður staðalmyndir og til pess noti Maximoff gjarnan hléin í frásögninni par sem hann fræðir lesandann; orðræðan hefur pá pað hlutverk „að gera við“, „laga“ og upplýsa og pannig leitast hann við að koma sínu fólki til varnar. ${ }^{26}$ Hins vegar hamri hann á pví hversu mikilvægt sé að kunna að lesa og skrifa. Í skáldsögunni Vinguerka lætur hann Papo segja eftirfarandi:

Ég vona að mörg ykkur eigi eftir að fara í skóla, og læra að lesa og skrifa, og verði jafnvel rithöfundar einn daginn. Pá mun ykkur bera skylda til pess að fræða aðra um ættflokk okkar, pað sem við höfum lifað og pað sem við lifum. Og ekki eins og pessir útlensku höfundar sem ímynda sér pað og segja svo frá. ${ }^{27}$

Pað leynir sér ekki að Maximoff tók sér einmitt petta hlutverk: að flytja menningu sína til peirra sem pekkja hana ekki, og pað gerði hann meðal annars með pví að skrifa sögur og segja frá. Pó svo að hann hafi kosið að skrifa á frönsku er móðurmál hans, rómíska, líka eitt af bví sem hann vill kynna fyrir lesendum sínum.

Próun rómískra bókmennta er stundum skipt í fjögur tímabil. ${ }^{28} \mathrm{Pad}$ fyrsta hefst með birtingu texta á rómísku í upphafi 20. aldar og á millistríðsárunum; annað tímabil hefst um miðja 20. öld pegar pó nokkrir rómískir höfundar gáfu út verk sín í Evrópu; priðja tímabilið hefst um 1980 pegar áhersla á menntun rómískra barna á móðurmáli peirra fer vaxandi; pað fjórða hefst um aldamótin en pá verður útgáfa bóka á rómísku útbreiddari. Markaðshugsun og sölumöguleikar hafa pó einnig haft áhrif á útgáfu verka á rómísku. ${ }^{29}$

26 Sama, bls. 88-89.

27 Matéo Maximoff, Vinguerka, Romainville: Chez l'auteur, 1987, bls. 49, sjá Kovácsházy, „Matéo Maximoff, romancier. Une vie pour la littérature“, bls. 89.

28 Sofiya Zahova, „Romani Literature: Historical Developments and Challenges of Internationalization“, Elena Marushiakova, Vesselin Popov (ritstj.), Roma Culture: Myths and realities, München: Lincom Academic Publishers, 2016, bls. 81-126, hér bls. 82-83.

29 Rómíska skiptist í fjóra mállýskuhópa með samtals 60-70 mállýskum. Ekki ríkir sátt um að nota eina mállýsku frekar en aðra sem ritmál. Pó er algengt að Vlax-mállýskur séu notaðar á albjóðlegum ráðstefnum eða fundum, en pær eru móðurmál um helmings Rómafólks. Kalderashmállýskan fellur í pennan hóp; Ian Hancock, We are the Romani People, bls. 139-149. 
раð er ekkert einsdæmi að rithöfundar kjósi að skrifa á öðru tungumáli en móðurmáli sínu, og geta ólíkar ástæður legið par að baki, t.d. menningarlegar pegar móðurmálið býr ekki yfir ritmáli, eða samfélagslegar, pegar annað tungumál er útbreiddara á pví málsvæði sem höfundarnir búa á. Sumir rithöfundar sem skrifa á öðru tungumáli en sínu eigin gera pað engu að síður á áhrifaríkan hátt. Hér má nefna kínverska rithöfundinn Xiaolu Guo sem skrifaði sínu fyrstu bók á ensku áđur en hún hafði nád góðum tökum á pví tungumáli og fjallaði par einmitt um menningarmun og misskilning. ${ }^{30}$ Bókin var gefin út með peim ambögum sem voru á ensku höfundar og pað kom ekki í veg fyrir að hún vekti mikla athygli og væri pýdd á fjölda tungumála. Af peim sem ritað hafa á frönsku má nefna ekki ófrægari rithöfunda en Samuel Beckett, Eugène Ionesco, Juliu Kristevu, og rithöfunda úr fyrri nýlendum Frakka, s.s. Ousmane Sembène frá Senegal, Assia Djebar, Yasmina Khadra og Kamel Daoud frá Alsír, og Tahar Ben Jelloun frá Marokkó. Pessi höfundar kjósa frönskuna fram yfir sitt móðurmál, arabískuna, af ólíkum ástæðum, en kannski ekki síst vegna pess að peir hafa að meira eða minna leyti hlotið menntun sína á frönsku og geta tjád á pví tungumáli hugsun sem hitt tungumálið rúmar ekki, eða að minnsta kosti ekki á sama hátt. Hvorki er hægt að alhæfa um samband peirra við móðurmálið né tungumálið sem pau nota í verkum sínum; hvert tilvik fyrir sig er einstakt og í pessu samhengi undirstrikar t.d. Assia Djebar að hún skrifi á „sinni“ frönsku, mon français. ${ }^{31}$

Höfundar af rómískum uppruna skrifa oftar en ekki á öðrum tungumálum en rómísku; stundum skrifa peir á tveimur tungumálum. ${ }^{32}$ Í endurminningum sínum sem austurrísk-rómíski rithöfundurinn Ceija Stojka skrifaði á pýsku segir frá bænum móður hennar í fangabúðum nasista: móðirin biður Guð um að bjarga börn-

30 Pað var bókin A Concise Chinese-English Dictionary for Lovers sem kom út í Bretlandi hjá Chatto \& Windus árið 2007. Bókin kom út í íslenskri býðingu Ingunnar Ásdísardóttur hjá bókaforlaginu Angústúra, 2019.

31 Um petta fjallar t.d. Irma Erlingsdóttir í grein sinni „,Tungumál útlegðar - Um skrif alsírska rithöfundarins Assiu Djebar“, Milli mála 2/2010, bls. 71-89.

32 раð getur einnig átt við um aðra höfunda, t.d. grænlenska rithöfundinn Niviaq Korneliussen, höfund Homo Sapienne sem kom út á grænlensku árið 2014 og höfundur býddi sjálfur á dönsku, sjá t.d. viðtal við skáldkonuna: https://www.rcinet.ca/eye-on-the-arctic/2017/12/01/enough-of-thispostcolonial-sh-an-interview-with-greenlandic-author-niviaq-korneliussen/ [skoðað 20. desember 2019]. 
unum sínum og allar bænir hennar eru skrifaðar á rómísku en býsk pýðing fylgir í sviga. ${ }^{33}$ Pess eru líka dæmi að höfundar býði sjálfir verk sín yfir á annað tungumál, t.d. skáldkonan Ilona Ferková sem skrifar á rómísku en hefur einnig pýtt sum verka sinna á tékknesku. Matéo Maximoff hafði mjög gott vald á móðurmáli sínu og sneri Nýja testamentinu og frönskum sálmum á rómísku eða öllu heldur Kalderash-mállýskuna. ${ }^{34}$ Langflest verka hans voru samin á frönsku og mun skýringin vera sú að hann vildi ná til peirra sem töluðu tungumál meirihlutans í Frakklandi. Alain Reyniers bendir á, í pessu samhengi, að í rómískum samfélögum sé munnmælahefðin mun sterkari en rithefðin og pví séu ritverk rómískra höfunda fyrst og fremst ætluð ekki-rómískum lesendum. ${ }^{35}$

Maximoff tekur fram, í inngangi að smásagnasafninu La poupée de Mameliga. Le livre de la peur, að sögurnar hafi allar verið sagðar af Kalderash-ættflokknum en séu pekktar vída um heim og tilheyri alpjóðlegum sagnaarfi; enginn standi í peirri trú að pær séu sannar enda bæti hver og einn við pær eftir smekk; pær séu gjarnan sagðar við varðeldinn pegar vakað er yfir líki, enda tengjast pær allar dauða og afturgöngum. ${ }^{36}$ Hann segist hafa skrád nokkur hundruð sögur og í pessari bók megi finna nokkrar peirra sem hann hafi umritad á frönsku. ${ }^{37}$

Sem ritmál er rómíska pví ekki ýkja gömul og ritaðar bókmenntir höfunda af rómískum uppruna bera pess merki að munnmælahefðin er enn sterk: verkin eiga gjarnan rætur í pjóðsagnaarfinum og rödd höfundar eða sögumanns heyrist af og til. Höfundar nota sögur sem peir hafa heyrt sem grunn að eigin verki; pannig verður pjóðsaga höfundarverk. Í sumum tilfellum fléttast inn í sög-

33 Sofiya Zahova, „The role of Romani language in Romani authors' works“, Andaj Romengi ljuma. Patjiv le Mozesoske Heinschink, Petra Cech, Christiane Fennesz-Juhasz, Dieter W. Halwachs (ritstj.), 2019, Graz: Grazer Romani Publikationen, bls. 347-369, hér bls. 359.

34 Cécile Kovácsházy, „Matéo Maximoff, romancier. Une vie pour la littérature“, bls. 76.

35 Sjá Alain Reyniers, „Les enjeux anthropologiques d'une culture romani de l'écriture“, Études Tsiganes 37(1)/2009, bls. 110-117. Sjá líka Sofiya Zahova, „The role of Romani language in Romani authors’ works“, einkum bls. 354-366 (,Flagging Romani identity through language“).

36 Раð er útbreiddur siður meðal margra Evrópupjóða að segja sögur við líkvökur, en sögur voru einnig sagðar við fleiri tækifæri, sjá Linda Dégh, Folktales and Society: Story-Telling in a Hungarian Peasant Community. Expanded Edition with a New Afterword, Bloomington og Indianapolis: Indiana University Press, 1969, einkum 6. kafli: „The Tale Occasions“, bls. 63-119, og Carl-Hermann Tillhagen, Taikon Berättar: Zigensagor, Stokkhólmi, 1946 (sjá einkum formála Tillhagens).

37 Matéo Maximoff, La poupée de Mameliga, bls. 19. 
urnar frásagnir höfunda af raunverulegum atburðum úr eigin lífi eða atburðum sem hafa haft sögulega merkingu fyrir rómíska samfélagið. Prátt fyrir framandi blæ og fjarlægt sögusvið, koma margar pær sögur sem finna má í smásagnasafninu La poupée de Mameliga. Le livre de la peur, íslenskum lesendum að mörgu leyti kunnuglega fyrir sjónir. Allar sögurnar í bókinni tengjast sama vel pekkta viðfangsefninu, óttanum - sem grípur manneskjuna andspænis endalokunum og hinu yfirnáttúrulega. Petta eru hálfgerðar hryllingssögur um dauða, refsingu og pau lögmál sem ríkja í samskiptum manna annars vegar og samskiptum manna við hið yfirnáttúrulega hins vegar, par sem mörkin eru óljós og gjarnan óvænt. Petta eru líka sögur um ást, sorg og missi. Allt kemur petta saman í pekktustu sögu verksins, „La poupée de Mameliga“, „Brúðu Mameligu“.38

Sagan fjallar um fátæka stúlku sem heitir Mameliga. Dag einn kemur hún til markaðsbæjar með foreldrum sínum og á göngu um markaðinn nemur hún staðar fyrir framan leikfangabúð og dáist að dúkkunum sem eru par til sýnis. Pá heyrir hún rödd sem spyr hana hvaða dúkka henni pyki fallegust. Hún snýr sér við og sér pá ungan mann, Igruska, sem kaupir handa henni fallegustu brúðuna prátt fyrir mótbárur Mameligu sem óttast viðbrögð foreldra sinna. Igruska segir henni að fjölskylda hans muni setja upp búðir við hlið fjölskyldu hennar petta sama kvöld. Ákveðið er að Mameliga og Igruska eigi að giftast og að brúðkaupið verði að ári liðnu. Næsta dag heldur fjölskylda unnustans áfram ferð sinni en fjölskyldurnar tvær mæla sér mót eftir prjá mánuði. Igruska er ópreyjufullur og áđur en hann kveður segir hann stúlkunni að hann muni koma að ná í hana fyrir pann tíma og hún verði að vera viðbúin að hlaupast á brott með honum.

Eina nóttina vaknar Mameliga við að henni finnst einhver vera fyrir utan tjaldið. Hún fer út, með brúðuna í fanginu, og sér pá Igruska sem er kominn að sækja hana. Hann kippir henni upp á hestinn fyrir aftan sig og pau ríða af stað í átt að heimili hans. Mameliga er dálítið óróleg, ekki síst vegna foreldra sinna, en hún er

38 Íslenska býðingu á pessari sögu er að finna í pessu hefti Milli mála, bls. 180-195. Hún mun einnig birtast í pví safni smásagna Rómafólks sem kemur út hjá Stofnun Vigdísar Finnbogadóttur árið 2020, sjá nmgr. 7. Petta er eina smásagnasafnið sem Maximoff sendi frá sér og bví eru allar smásögur hans sem hér eru nefndar úr pessu riti. 
líka glöð yfir pví að vera með heitmanni sínum. Eftir eina klukkustund sér hún vagna og tjöld tengdafjölskyldunnar og par fyrir aftan mótar fyrir kirkjuturni. Hún furðar sig á pví að pau skuli ekki stansa hjá vögnunum heldur halda rakleiðis inn í kirkjugarðinn. Pegar hann nemur loks staðar við opna gröf skilur Mameliga að Igruska elskar hana svo heitt að hann hefur komið til hennar úr handanheimum. Hann býður henni að koma niður í gröfina og réttir henni höndina. Skelfingu lostin rífur hún blússuna sína í ræmur, og svo kjólinn, og setur snifsin, eitt á fæutur öðru, í útrétta höndina. Pegar hún stendur nakin við opna gröfina grípur hún brúðuna og slítur af henni perlufesti sem hún hafði sett um háls hennar, tekur perlurnar og leggur í lófa Igruska, eina af annarri, par til aðeins prjár perlur eru eftir. Pá galar haninn og jörðin gleypir afturgönguna.

Mameliga hleypur eins og fæur toga til kirkjunnar, grípur par í tjald til að hylja nekt sína, klifrar svo upp í kirkjuturninn og hringir klukkunni. Ungur prestur svarar kallinu og hjálpar henni að finna foreldra Igruska sem segja henni að sonur peirra hafi lent í slagsmálum deginum áđur og dáið.

Í athugasemd sinni við „Brúðu Mameligu“ segir Maximoff að pessi saga hafi verið mjög útbreidd hjá Rómafólki en fallið í gleymsku eftir að kristni breiddist út meðal peirra; hann vilji pó koma í veg fyrir að pessar gömlu sögur gleymist endanlega pótt hann sé prestur. Hann játar að hafa sjálfur reynslu af yfirnáttúrulegum fyrirbærum, s.s. afturgöngum, sem hann geti ekki með nokkru móti útskýrt, en bætir svo við að Guð muni eyða myrkraverkum djöfulsins. ${ }^{39}$

„Brúða Mameligu“ minnir íslenskan lesanda óneitanlega á söguna af „Djáknanum á Myrká“, eina af pekktustu draugasögunum í safni

39 La poupée de Mameliga, bls. 184-185. Milena Hübschmannová bendir á að sagan sé vel pekkt í rússnesk-rómískum bókmenntum og víðar í Austur-Evrópu; Milena Hübschmannová, „Matéo Maximoff“. Hún er af pjóðsagnagerðinni ATU 365 og er reyndar vel pekkt í allri Evrópu, sjá t.d. ensku ballöðuna „The Suffolk Miracle“, sem fyrst birtist á prenti á árunum 1678-1680. Um flokkunarkerfi pjóðsagna og „finnska skólann“ má t.d. lesa í inngangi Hans-Jörgs Uther, The Types of International Folktales: A Classification and Bibliography Based on the System of Antti Aarne and Stith Thompson, 3 bindi. FF Communications nos. 284-86, Helsinki: Suomalainen Tiedeakatemia, 2004, bls. 7-15, og um ATU 365 á bls. 229. Sjá einnig: Rósa Porsteinsdóttir, Sagan upp á bvern mann, Reykjavík: Stofnun Árna Magnússonar í íslenskum fræðum, 2011, bls. 22-26 og bls. 61-64. 
Jóns Árnasonar, sem kom fyrst út á árunum 1862 og 1864..ํ Sagan gerist um jólaleytið, í Eyjafirði. Petta er dimmasti tími ársins og algengt er í íslenskri pjóðsagnahefð að tröll, afturgöngur og huldufólk séu pá á ferð. Nokkru fyrir jól fer djákninn á Myrká að Bægisá og býður stúlkunni sinni til jólagleði að Myrká. Áin Myrká rennur á milli bæjanna tveggja og pennan dag gerði asahláku með úrkomu og vatnavöxtum og á bakaleiðinni lendir djákninn í ánni og drukknar. Lík hans rekur upp á bakkann hinum megin en vegna óveðursins er ekki hægt að senda boð um dauða hans til stúlkunnar. 24. desember kemur djákninn rîđandi að ná í stúlkuna. Pau tvímenna á hestinum hans og pegar pau eru að fara yfir ána brýst tunglið fram úr skýjunum og stúlkan sér hvítan blett í hnakka djáknans sem situr fyrir framan hana. Pegar bau koma að Myrká sér stúlkan opna gröf í kirkjugarðinum. Skelfingu lostin hleypur hún að klukknahliðinu og hringir. Pá finnur hún að gripið er í hempuna hennar svo hún rifnar. Hún snýr sér við og sér hvar djákninn fellur ofan í gröfina, með bút af hempunni. Gröfin fyllist og hann hverfur.

Smásagan „Brúða Mameligu“ er pví bæði framandi og kunnugleg íslenskum lesendum og margt er líkt með pessum tveimur sögum: veisla/hátíð, bið, látinn maður vitjar konu sem hann elskar, ferð í myrkri, kirkja og kirkjugarður, opin gröf, rifin klæði, kirkjuklukkur sem koma til bjargar. Pó er margt sem skilur pær að: landslag og baksvið „Brúðu Mameligu“ eru ólík ólgandi ánni og vetrarhörkunni í „Djáknanum á Myrká“ og frásagnarmátinn er frábrugðinn. Рað er einkenni munnmælasagna að breytast í hvert sinn sem pær eru sagðar og aðlagast stund og stað, menningu og samfélagi. Рað má einnig hafa í huga að pegar Maximoff sendi frá sér smásagnasafnið La poupée de Mameliga. Le livre de la peur árið 1986 hafði hann pegar gefið út fimm skáldsögur. Hann var orðinn reyndur rithöfundur pótt bókmenntir Rómafólks hafi pá verið og séu enn ungar bókmenntir í peim skilningi að rithefðin er ung. „Brúða Mameligu“ er til að mynda mun flóknari en sagan um „Djáknann á Myrká“ og Maximoff fléttar frásögnina í kringum litla tuskubrúðu, sem er í raun tvífari Mameligu. Auk pess byggir hann upp meiri spennu í sögunni og heldur lesandanum í óvissu um örlög Igruska par til undir lok verks-

40 Jón Árnason, Íslenzkar pjöóö̈gur og avintýri, Leipzig: J.C. Hinrichs, 1862-1864, bls. 270-271. 
ins. Eins og víðar í verkum Maximoffs ber pó sagan ýmis merki munnlegrar hefðar.

Sögukonan Mameliga er orðin langamma pegar hún segir sögu sína og hún byrjar á pví að útskýra stöðu kvenna meðal Rómafólks, hvernig raddir peirra máttu ekki heyrast hér áđur fyrr pegar karlmenn voru viðstaddir, en nú geti karlarnir einfaldlega ráðið pví sjálfir hvort peir hlusti á konurnar eða ekki! Síoan lýkur hún frásögninni með pví að taka fram að pað sé ómögulegt „að gleyma svona nokkru“.41 Parna minnir Maximoff á meistara smásögunnar í Frakklandi, Guy de Maupassant, sem hafði gjarnan pann háttinn á að leiða lesandann inn í frásögnina með inngangi sögumanns og láta sögumanninn taka aftur til máls í lokin.

Eitt af pví sem einkennir smásögur Maximoffs, eins og önnur skrif hans, er notkun rómísku. Sofiya Zahova hefur fjallað um notkun rómísku í verkum rithöfunda af rómískum uppruna. ${ }^{42}$ Hún bendir á að orðin sem birtist í textanum séu ekki gripin úr lausu lofti, pau séu par ekki fyrir tilviljun heldur séu pau notuð markvisst til að minna lesandann á uppruna textans, um pá menningu og pað samfélag sem hann er sprottinn úr enda vísi pau iðulega til ákveðinna pátta í siðum og lögum Rómafólks, jafnvel grundvallarhugtaka sem höfundurinn telur einkennandi fyrir sína menningu og vill að lesandinn taki sérstaklega eftir. Með pví að nota rómísk orð undirstrikar höfundur pannig uppruna textans, sjálfsmynd sína og peirra sem hann skrifar um, en um leið aðgreinir hann sig frá „hinum“, peim sem ekki tilheyra hans menningu, peim sem eru ekki-rómískir og Maximoff kallar „les Gayziés“. ${ }^{3}$ Væntanlega er petta pað sem vakir fyrir Maximoff pví að pað er ekki nóg með að lesandinn hnjóti um rómísk orð á nánast hverri blaðsíou heldur er hann sífellt minntur á uppruna sögupersónanna. Hér eru nokkur af peim orðum sem bregður fyrir hjá Maximoff í smásagnasafninu La poupée de Mameliga ${ }^{44}$ :

\footnotetext{
41 Matéo Maximoff, La poupée de Mameliga, bls. 169-170 og bls. 184.

42 Sofiya Zahova, „The role of Romani language in Romani authors’ works“, bls. 354-366. Hún gefur ýmis dæmi.

43 Sjá Mozes F. Heinschink, Michael Teichmann, „Gadscho (Gadzo)/Das/Gor“, ROMBASE.

44 Sjá t.d. Norbert Boretzky, Birgit Igla, Wörterbuch Romani - Deutsch - Englisch für den südosteuropäischen Raum: Mit eine Grammatik der Dialektvarianten, Wiesbaden: Harrassowitz Verlag, 1994.
} 


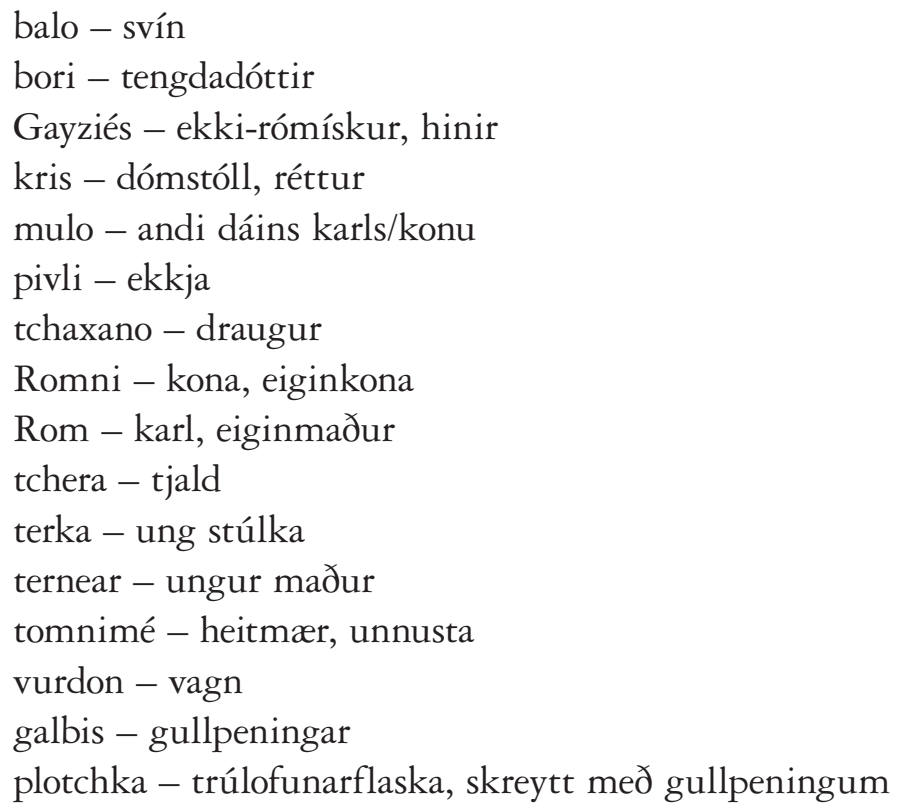

Notkun erlendra orða í texta getur verið vandasöm, ekki síst pegar algeng orð sem auðvelt er að pýða eiga í hlut. Höfundur metur pað sjálfur hvort hann kýs að hafa erlend orð í texta sínum; pýðandi vinnur hins vegar með texta par sem ákvörðunin hefur pegar verið tekin pegar hann kemur að textanum. Hann hefur auk pess pað hlutverk að miðla verkinu til nýrra lesenda, merkingu pess, yfirbragði og stíl. Рað er pví sjálfsagt að hann virði pá ákvörðun höfundar að hafa erlend orð í textanum og pýði pau ekki. pað kemur pó ekki í veg fyrir að sú ákvörðun vekji ýmsar spurningar, ekki síst varðandi merkingu og skilning. Раð er efalítið auðvelt fyrir flesta íslenska lesendur að skilja orð eða setningu á ensku í býddu verki. Í íslenskri býðingu Jóhönnu Bjarkar Guðjónsdóttir á fransk-kanadísku skáldsögunni Nirliit eftir Juliana Léveillé-Trudel, sem gerist í norðanverðu Québecfylki í Kanada, má til dæmis finna pessar stuttu setningar: „I love you! May I have your number? Can I run with you?"45 Pýðandinn gerir væntanlega ráð fyrir að lesandinn skilji pessar setningar og býðir pær ekki, en pegar orðum úr tungumáli inúíta bregður fyrir fylgir pýðing, til dæmis quallunaat „hvítt fólk“ (bls. 15 og 21) og uppialuk

45 Juliana Léveillé-Trudel, Nirliit, Reykjavík: Dimma, 2019, bls. 68. 
„snæugla“ (bls. 138) pótt fyrra orðið sé ekki alltaf pýtt í franska frumtextanum og pað síðara sé ekki býtt. ${ }^{46}$ Í skáldsögunni Allt sundrast eftir Chinua Achebe, sem kom út á ensku árið 1958, er mikið af orðum úr ibo-tungumálinu, sem er móðurmál höfundarins. Í íslenskri býðingu Elísu Bjargar Porsteinsdóttur frá 2018 eru orðin pýdd í fyrsta sinn sem pau birtast, stundum oftar, en lesandinn getur bó ekki treyst pví, eins og hér: „,,Umuofia kwenu!“ hrópaði foringi egwugwu og sló bastklæddum handleggjunum út í loftið““. 47 Fyrir gleyminn lesanda er svo orðalisti aftast í bókinni. Achebe hefur sjálfur orðalista í enskri útgáfu verksins, en bætir af og til pýðingu við orðin pegar pau birtast í textanum - pó sjaldnar en íslenski pýðandinn sem er örlítið hjálplegri við lesandann. ${ }^{48}$

Pegar Matéo Maximoff notar rómísku í smásögum sínum læur hann oftast franska býðingu fylgja með innan sviga í fyrsta sinn sem orðið birtist í hverri sögu, eða skýrir orðið með inngripi sögumanns eins og hér, í smásögunni „La pomana“ (Pomana):

C'était la pomana. Tu sais ce que c'est que la pomana ? C'est l'anniversaire de la mort de quelqu'un. (bls. 164)

Í býðingu:

Pað var pomana. Veistu hvað pomana er? Pað er pegar einhver á dánarafmæli.

Hann hefur ekki orðalista aftast í bókinni og gerir á vissan hátt pá kröfu til lesandans að hann leggi merkingu orðanna á minnið, að minnsta kosti í dálítinn tíma. Gleyminn lesandi parf pví að rekja sig til baka í textanum í leit að pýðingu. Eins og Sofiya Zahova bendir á mætti auðveldlega pýða pau rómísku orð sem ekki hafa sértæka merkingu á markmáli pýðingarinnar; pað sé hins vegar ætlun og vilji höfundanna sem nota tungumál sitt á pennan hátt að orðin standi ópýdd. ${ }^{49}$ Við pýðingu á smásögum Maximoffs ákvað ég að fylgja notkun höfundar á rómísku orðum í frumtexta: skáletra og hafa

46 Ég pakka Jóhönnu Björk Guðjónsdóttur kærlega fyrir upplýsingar um pýðingar á inúítaorðum í frumtexta Nirliit.

47 Chinua Achebe, Allt sundrast, Reykjavík: Angústúra, 2018, bls. 114.

48 Sjá Chinua Achebe, Things fall apart, Anchor Books, 1994 (1959).

49 Sofiya Zahova, „The role of Romani language in Romani authors' works“, bls. 357. 
býđingu innan sviga pegar bau birtast í fyrsta sinn en skáletra annars til aðgreiningar. Раð kemur pó ekki í veg fyrir að pýðandinn staldri við pann ásetning höfundar að halda orðum af erlendum uppruna inni í textanum, sem ekki stendur til að laga að íslensku beygingakerfi og auðveldlega mætti pýða eins og í eftirfarandi dæmi. Í smásögunni „L'histoire de Diordi Zachari“ (Sagan um Diordi Zachari) birtist dauðinn eða andi dáins manns (mulo) í svínslíki (balo) par sem tveir menn eru á ferð í hestvagni (vurdon) og hrellir pá sem á vegi hans verða:

Dans ses bras, le balo avait soudain grossi. A ce point qu'il était impossible à Mitia de s'en débarrasser. J'ai arrêté le vurdon. Ah! nous n'étions pas au bout de notre stupeur. Voici que le balo s'était mis à parler comme un Rom. (bls. 73)

Í pýðingu:

Balo sem hann hélt á fanginu hafði stækkað svo mikið að Mitia gat ekki losað sig við hann. Ég stoppaði vurdon. En við urðum enn meira undrandi pegar balo fór allt í einu að tala eins og Rómamaður.

Pegar verk Maximoff eiga í hlut, má hafa í huga að í frönsku eru nafnorð ekki beygð og ákveðinn greinir stendur fyrir framan orðið. раð er pví nokkuð auðvelt að fella ný orð inn í tungumálið. Í íslensku verður að sleppa ákveðna greininum nema pegar pýðing fylgir innan sviga í frumtexta. Lýsingarorð má laga að kyni íslenska orðsins:

Ainsi, Pazel est désormais Pivli (veuve). (bls. 49)

Í býðingu:

Pannig að nú er Pazela orðin Pivli (ekkja).

Soutenu par Grofo, la Pivli pleure. (bls. 49)

Í pýðingu:

Pivli grét og Grofo studdi hana.

Mitra descendit du vurdon (voiture) pour le tirer par la bride. (bls. 72) 
Í pýðingu:

Mitra fór niður úr vurdon (vagninum) og ætlaði að toga hann áfram á beislinu.

C'était un tout petit balo (cochon). (bls. 72)

Í pýðingu:

Petta var pínulítið balo (svín).

Sum orð mætti laga að beygingarkerfi íslenskunnar, sbr. nafnorðið terka „stúlka“ sem hægt er að beygja: terka, terku, terku, terku, og gæti jafnvel borið viðskeyttan greini:

Mais pourquoi est-ce que tu n'es pas encore mariée? Ma terka, qui a ton âge, l'est déjà. (bls. 171)

Í pýðingu :

En hvernig stendur á pví að pú ert enn ógift? Mín terka (stúlka), sem er jafngömul pér, er gift.

eða:

En hvernig stendur á pví að pú ert enn ógift? Terkan (stúlkan) mín er jafngömul pér og hún er gift.

Að lokum má benda á að Maximoff notar iðulega orðin Rom og Romni í stað nafnorðanna „karl“, „eiginmaður“ og „kona“, „eiginkona“. Í upphafi skáldsögunnar Condamné à surviure lýsir hann pví hvernig tilviljun ein ræður pví hvar einstaklingur af rómískum uppruna er jarðsettur: „le Rom est enterré là où il meurt“ (Rómamaður er jarðaður par sem hann deyr). Í öðrum tilvikum fer betur á pví að pýða Rom sem „eiginmaður/karl“ og Romni sem „eiginkona/kona“:

Tripka sera mon Rom et personne d'autre. (bls. 51)

Í pýðingu:

Tripka verður eiginmaður minn, og enginn annar!

Cela étant fait, je rentre chez moi, rassuré : ma Romni ne sera plus jamais malade. (bls. 56) 
Í býðingu:

Að pví loknu fór ég heim, viss um að konan mín yrði aldrei aftur veik.

Í smásögunni „L'amour chez les Tziganes“ (Sígaunaást) notar Maximoff bæði frönsku og rómísku, hlið við hlið:

Désormais, Frinka et Louloudji étaient considérés comme mari et femme, comme rom et romni. (bls.156)

Í pýðingu:

Upp frá pví voru Frinka og Louloudji eiginmaður og eiginkona, rom og romni.

Pessi klifun minnir lesandann í sífellu á að sögurnar eru um Rómafólk en einnig að pær eru ekki samdar með rómíska lesendur í huga, heldur hina, Gayziés. Erlendu orðin reyna e.t.v. örlítið á gestrisni markmálsins og polinmæði lesandans, sem er ókunnugur tungumálinu. Hafi Maximoff viljað upplýsa og fræða lesandann um sjálfsmynd Rómafólk, menningu peirra og tungumál má einnig velta pví fyrir sér hvort rómísku orðunum sé líka ætlað að halda ekki-rómíska lesandanum í ákveðinni fjarlægð með pví að minna hann einmitt á með reglulegu millibili að hann er Gayziés í peim heimi sem verið er að lýsa?

Matéo Maximoff var einn af bekktari rithöfundum Rómafólks á 20. öld. Hann var meðvitaður um eigin sögu, menningu og sjálfsmynd og gerði skýran greinarmun á pví að verða rómískur og ekki-rómískur, Gayziés, í verkum sínum. Hann tilgreindi sjaldan hvaða rómíska ættflokki hinar og pessar sögupersónur í verkum hans tilheyra; hann dró öllu heldur upp sameinandi mynd af Rómafólki: hann og minningar hans, sögurnar sem hann heyrði, skáldskapur hans og örlög sögupersónanna verða sameiginleg örlög alls Rómafólks í augum pess sem les. Í pví samhengi hefur verið bent á epíska vídd í verkum hans. Í íslenskri pýðingu á nokkrum smásögum Maximoffs 
úr bókinni La poupée de Mameliga. Le livre de la peur hef ég fylgt peirri ákvörðun höfundar að hafa rómísk orð í textanum. Pau eru hluti af peirri sjálfsmynd sem Maximoff dregur fram af Rómafólki; pau eru vissulega framandi en pau gera lesandanum engu að síður kleift að komast nær peim menningarheimi sem textinn er sprottinn úr. 


\section{Sjálfsmynd, framandleiki og tungumál í verkum Matéos Maximoff: rómíska í íslenskum pýðingum}

Menning Rómafólks er lítið pekkt á Íslandi og nánast engin verk eftir rithöfunda af rómískum uppruna hafa verið pýdd á íslensku. Fágætt er að rómískir höfundar skrifi verk sín á rómísku pótt pess séu dæmi. Rithöfundurinn og sagnamaðurinn Matéo Maximoff samdi til dæmis flest sín verk á frönsku. Eins og fleiri rómískir rithöfundar á 20. öld vildi hann gera sögu og menningu Rómafólks góð skil í skáldverkum sínum til að fræða lesendur um líf pess og samfélag. Рað gerir hann meðal annars með pví að skjóta inn fróðlegum upplýsingum um siði og sögu Rómafólks en einnig með pví að nota bæði orð og setningar á tungumáli peirra. Petta á bæði við um sértæk orð, sem eiga ekki hliðstæðu í öðrum tungumálum, og orð sem eiga hliðstæðu í öðrum tungumálum og auðvelt væri að pýða yfir á markmál býðingarinnar. Hér er sagt frá verkum og hugarheimi Matéos Maximoff og notkun rómískra orða í skáldverkum hans. Dæmi verða tekin úr íslenskri býðingu á nokkrum sögum úr smásagnasafninu La poupée de Mameliga. Le livre de la peur (Brúða Mameligu. Bók óttans). Rómísku orðin gefa franska frumtextanum framandi yfirbragð og pau fylgja textanum inn í pýðinguna.

Lykilorł: La poupée de Mameliga, Matéo Maximoff, rómíska, smásögur, sjálfsmynd 


\section{Identity, exoticism and language in the works of Matéo Maximoff: Romani in Icelandic translations}

Roma culture is not well known in Iceland and hardly any works of Roma writers have been translated into Icelandic. Roma writers rarely write their works in Romani. The writer and story-teller Matéo Maximoff, for instance, wrote most of his works in French. As many other Roma writers in the 20th century, he wished to give a good account of the Roma people's history and culture in order to instruct the reader about their life and community by providing various information about their customs and traditions, but also by using both words and short sentences in Romani. This both refers to particular words with no equivalent in other languages as well as words that do have an equivalent in another language and could therefore be easily translated into the target language. This article presents the works and the fictive world of Matéo Maximoff as well as his use of Romani words in his writings in French. Examples will be taken from some of the short-stories in the collection La poupée de Mameliga. Le livre de la peur (Mameliga's Doll. The Book of Fear). The Romani words add a certain exoticism to the French original and they can also be found in the translated text.

Keywords: La poupée de Mameliga, Matéo Maximoff, Romani, shortstories, identity 